\title{
Correction to: Diversity and evolution of the transposable element repertoire in arthropods with particular reference to insects
}

Malte Petersen ${ }^{1,9,10^{*}} \mathbb{1}$, David Armisén ${ }^{2}$, Richard A. Gibbs ${ }^{3}$, Lars Hering ${ }^{4}$, Abderrahman Khila ${ }^{5}$, Georg Mayer ${ }^{6}$, Stephen Richards ${ }^{7}$, Oliver Niehuis ${ }^{8}$ and Bernhard Misof ${ }^{9}$

\section{Correction to: BMC Ecol Evo (2019) 19:11}

https://doi.org/10.1186/s12862-018-1324-9

Following publication of the original article [1], we were notified that the Dryad Digital Repository link under "Availability of data and materials" was missing a dot. The correct link is: https://datadryad.org/stash/dataset/doi: 10.5061/dryad.55p667b.

The original article has been corrected.

\begin{abstract}
Author details
${ }^{1}$ University of Bonn, Bonn, Germany. ${ }^{2}$ Université de Lyon, Institut de Génomique Fonctionnelle de Lyon, CNRS UMR 5242, Ecole Normale Supérieure de Lyon, Université Claude Bernard Lyon 1, 46 allée d'Italie, 69364 Lyon, France. ${ }^{3}$ Human Genome Sequencing Center, Department of Human and Molecular Genetics, Baylor College of Medicine, Houston 77030 TX, USA. ${ }^{4}$ Department of Zoology, Institute of Biology, University of Kassel, Heinrich-Plett-Str. 40, 34132 Kassel, Germany. ${ }^{5}$ Université de Lyon, Institut de Génomique Fonctionnelle de Lyon, CNRS UMR 5242, Ecole Normale Supérieure de Lyon, Université Claude Bernard Lyon 1, 46 allée d'Italie, 69364 Lyon, France. ${ }^{6}$ Department of Zoology, Institute of Biology, University of Kassel, Heinrich-Plett-Str. 40, 34132 Kassel, Germany. ${ }^{7}$ Human Genome Sequencing Center, Department of Human and Molecular Genetics, Baylor College of Medicine, Houston, TX 77030, USA. ${ }^{8}$ Department of Evolutionary Biology and Ecology, Institute for Biology I (Zoology), University of Freiburg, 79104 Freiburg (Brsg.), Germany. ${ }^{9}$ Zoological Research Museum Alexander Koenig, Center for Molecular Biodiversity Research, Adenauerallee 160, 53113 Bonn, Germany. ${ }^{10}$ Senckenberg
\end{abstract}

Gesellschaft Für Naturforschung, Senckenberganlage 25, 60325 Frankfurt, Germany.

Published online: 16 July 2021

\section{Reference}

1. Petersen M, Armisén D, Gibbs RA, Hering L, Khila A, Mayer G, Richards S, Niehuis $\mathrm{O}$, Misof B. Diversity and evolution of the transposable element repertoire in arthropods with particular reference to insects. BMC Evol Biol. 2019;19:11. https://doi.org/10.1186/s12862-018-1324-9.

\section{Publisher's Note}

Springer Nature remains neutral with regard to jurisdictional claims in published maps and institutional affiliations. original author(s) and the source, provide a link to the Creative Commons licence, and indicate if changes were made. The images or other third party material in this article are included in the article's Creative Commons licence, unless indicated otherwise in a credit line to the material. If material is not included in the article's Creative Commons licence and your intended use is not permitted by statutory regulation or exceeds the permitted use, you will need to obtain permission directly from the copyright holder. To view a copy of this licence, visit http://creativecommons.org/licenses/by/4.0/. The Creative Commons Public Domain Dedication waiver (http://creativeco mmons.org/publicdomain/zero/1.0/) applies to the data made available in this article, unless otherwise stated in a credit line to the data. 